\title{
Agricultural Unskilled Labor Mobility: Does It Matter?
}

\author{
Mustafa ACAR \\ Kýrýkkale University
}

\begin{abstract}
Labor mobility is an important issue in quantitative economic analyses due to its possible implications for the sectoral reallocation of factors of production, output response, prices, and wages. This paper investigates the issue of agricultural unskilled labor mobility from both modeling and empirical perspectives. After discussing the issue from a theoretical perspective, I look into the empirical implications of treating agricultural unskilled labor less than mobile in the context of Turkey-EU agricultural integration. The results indicate that degree of mobility of the agricultural unskilled labor matters. It has certain implications on sectoral reallocations, and accordingly factor returns. The higher the degree of unskilled labor mobility between farm and non-farm sectors, the higher the output response, and the lower the real earnings of unskilled labor in agriculture.
\end{abstract}

- JEL Classifications: F02, J43, J60, R23, D58

- Key words : Labor mobility, Agriculture, Regional integration, General equilibrium

\section{Introduction}

Labor mobility is an important issue in quantitative economic analyses due to its possible implications for the sectoral reallocation of factors of production, output response, prices, and wages. Hertel (1989) highlights the importance of agricultural technology and factor mobility in determining the impact of changing support policies. Under normal circumstances, the more mobile is the labor between

*Corresponding address: Professor Mustafa ACAR, Kýrýkkale University, Department of Economics, Kýrýkkale, Turkey. Tel.: +90-533-632 4766, Fax: +90-312-433 1112, E-mail: acar_m@yahoo.com (C)2003-Center for International Economics, Sejong Institution, All Rights Reserved. 
sectors, the higher the supply response we would expect to trade policy reforms. Impact on returns to sector-specific factors is also a key issue in the context of labor mobility.

In the ideal world of neoclassical frictionless markets, labor is perfectly mobile between sectors and responds instantaneously to wage differentials. However, in the real world we usually observe various kinds of frictions between markets, which adversely affect the mobility of the factors. In particular, perfect mobility assumption becomes more questionable when it comes the mobility of the relatively less skilled agricultural labor between farm and non-farm sectors.

Many empirical studies are skeptical about the labor mobility between agricultural and non-agricultural sectors, and question if labor market clearing is realized between these markets. Even though Barkley (1990) shows that migration from agriculture responds to relative wage differentials between sectors, he argues that the labor migration to higher wages does not take place immediately due to the uncertainty of getting a job in the other sector. Similarly, Patterson (1998) argues that for economists American fruit and vegetable growers' notion of a shortage of agricultural labor implies an excess demand at the prevailing wage. This situation would normally cause agricultural wages to go up, inducing a labor inflow from other sectors until the shortage disappears. However, this equilibration of wages, hence market-clearing process does not appear to be occurring statically, as would be suggested by the neoclassical economic theory.

Alston and Hatton (1991) interpret differences between wages in agriculture and manufacturing in the early 1900s as evidence of a permanent disequilibrium, or nonintegration, between farm and non-farm sectors. Hatton and Williamson (1991a) cite that "unskilled fulltime nominal urban wages are about $41 \%$ higher than farm wages in the contemporary Third World" (Squire, 1981, p.102), and "they were about $51 \%$ higher among late $19^{\text {th }}$-century industrializers" (Clark, 1957, pp.526-531). The wage gap was even higher in England in the 1830s, about $73 \%$, and about $50 \%$ in the United States in the mid-1890s (Williamson, 1987).

However, Hatton and Williamson found that this $50 \%$ nominal gap collapses to 9-13\% urban-agricultural real wage gap after correcting for differences in the cost of living, personal (human capital) characteristics, perquisites ${ }^{1}$ received by farm laborers, and urban unemployment. They conclude that their findings imply for the transfer of labor out of agriculture that the measured gaps are smaller than often believed, suggesting that labor mobility was not perfect, but complete market segmentation was not the case, either. Similarly, in another paper (1991b) on 
America from 1890 to WWII Hatton and Williamson found that unemployment and wage differentials played the roles predicted by Todaro, but migration was not sufficiently elastic to equilibrate the returns to rural and urban unemployment. Thus, they concluded, "the labor markets linking farm to city did not work perfectly, but they worked well enough to keep the wage gap within relative narrow bounds" (Hatton and Williamson; 1991a, p.406).

In light of the above discussion, agricultural unskilled labor mobility can be considered important for developing countries in search of regional economic integration. Given the fact that the economy in these countries rely more heavily on agriculture, regional integration with a group of countries in the form of customs union or free trade area might have important implications for these countries, depending on the degree of mobility of agricultural labor. In this context, this paper is an attempt to model agricultural unskilled labor mobility and investigate its empirical implications in a multi-sector general equilibrium framework. The rest of the paper is organized as follows.

Section II discusses modeling agricultural unskilled labor mobility. Section III presents the results obtained from applying this model to a regional integration project, i.e. Customs Union between Turkey and the $E U$. Conclusions follow.

\section{Modeling Agricultural Unskilled Labor Mobility}

In order to address the issue of agricultural unskilled labor mobility, this study extends the standard Global Trade Analysis Project (GTAP) modeling framework developed by Hertel $(1997)^{2}$. First the issue of factor mobility will be reviewed in a general context as tackled by the standard model. And then details of the extension on how to model unskilled labor mobility will follow.

Partial equilibrium supply response to a change in output price, in a neoclassical applied general equilibrium model with constant returns to scale, is determined mainly by two factors: technology and factor mobility. Interaction between these two factors would also affect supply response. When all inputs are perfectly mobile and input prices are exogenously determined ${ }^{3}$, then supply is perfectly

\footnotetext{
${ }^{1}$ Payments or profits received in addition to regular wages or salaries.

${ }^{2} G T A P$ is a project dedicated to the development and support of a global research network, data base, and modeling framework for conducting quantitative analysis of international trade, environment and resource issues in an economy wide framework. For the standard GTAP Model, see Hertel (1997).

${ }^{3}$ This is a common partial equilibrium assumption.
} 
elastic at the output price determined by the unit costs, implying a horizontal supply curve. Only the factor endowment constraints will reduce supply response in this case. However, once one of the inputs is treated less-than perfectly mobile then technology comes into play as another factor affecting supply response. Sectoral supply response becomes a function of the industry's ability to substitute away from the fixed factor of production.

Following Hertel (2000), supply response (i.e. partial equilibrium supply elasticity) for the case of a single, specific factor, can be derived as follows. Let us start with derivation of the zero profit condition. Starting from the production function

$$
Q=f\left(Q_{1}, \ldots, Q_{N}\right)
$$

where $Q$ denotes output, and $Q_{1}, \ldots ., Q_{N}$ denote all inputs used in the production process. Totally differentiating Equation (1) yields:

$$
\begin{gathered}
d Q=(\delta f / \delta Q 1) d Q+\ldots .+\left(\delta f / \delta Q_{N}\right) d Q_{N} \text { or, letting } \delta f / \delta Q_{i}=f_{i}(i=1, . . N) \text { we have } \\
d Q=\Sigma_{i} f_{i} d Q_{i}
\end{gathered}
$$

where $f_{i}$ refers to the marginal value product of input $i^{4}$

Cost minimizing firms will equate the marginal value product of each input with its cost (i.e. price of input, $p_{i}$ ):

$$
p_{i}=p f_{i} \text { or } f_{i}=p_{i} / p
$$

Substituting (4) in (3) for $f_{i}$ we get:

$$
d Q=\Sigma_{i}\left(p_{i} / p\right) d Q_{i}
$$

Multiplying the terms in the summation by $\left(Q_{i} / Q_{i}\right)$ and dividing the whole equation by $\mathrm{Q}$ gives:

$$
(d Q / Q)=\Sigma_{i}\left(p_{i} Q_{i} / p Q\right) d Q_{i} / Q_{i}
$$

\footnotetext{
${ }^{4}$ Marginal Value Product of input $i=$ Marginal Physical Product of $i\left(f_{i}\right) x$ price of output $(p)$
} 
Multiplying through by $100 \%$ to convert the quantity changes to percentages and noting that the sum in parentheses on the right-hand side is simply a cost share, we have:

$$
q=\Sigma_{i} \theta_{i} q_{i}
$$

where $q$ is $\%$ change in output, $\theta_{i}$ is cost share and $q_{i}$ is $\%$ change in quantity of inputs.

Therefore, for the cost-minimizing firm, percentage change in output is simply a cost-share-weighted sum of the input changes. This relationship can be utilized in deriving the zero profit expression as follows. Competitive entry and exit in an industry will eventually drive the industry to zero profit equilibrium where total revenue equals total cost:

$$
P Q=\Sigma_{i} P_{i} Q_{i}
$$

where $P$ is output price, $Q$ is output quantity, $P_{i}$ is input price and $Q_{i}$ is input quantity. Totally differentiating (8) yields:

$$
(Q d P+P d Q)=\Sigma_{i}\left(Q_{i} d P_{i}+P_{i} d Q_{i}\right)
$$

Dividing through by $P Q$ gives:

$$
(d P / P+d Q / Q)=\Sigma_{i}\left(Q_{i} d P_{i}+P_{i} d Q_{i}\right) / P Q
$$

Multiplying the right-hand side terms by $\left(Q_{i} / Q_{i}\right)$ and $\left(P_{i} / P_{i}\right)$, respectively, using the definition of "cost share," and multiplying through by $100 \%$ yields:

$$
p+q=\Sigma_{i} \theta_{i}(p i+q i)
$$

which says that $\%$ change in output price plus $\%$ change in output quantity equals costshare weighted sum of $\%$ changes in input prices and quantities.

Rearranging right-hand side of (11) and making use of (7) we obtain the desired zero profit condition: ${ }^{5}$

\footnotetext{
${ }^{5} p+q=\Sigma_{i} \theta_{i}\left(p_{i}+q_{i}\right)=\Sigma_{i} \theta_{i} p_{i}+\Sigma_{i} \theta_{i} q_{i}$. Since the second term equals $q$ (eq. 7) they drop out, hence we are left with Eq. 12.
} 


$$
p=\Sigma_{i} \theta_{i} p_{i} \quad \text { (zero profit condition) }
$$

Next step is to derive the labor supply equation in percentage change form linking output price and wages. For simplicity, suppose labor input is immobile across sectors, which implies that there are as many different types of labor as there are sectors in the model. This, in turn, implies that there are as many wage rates as there are labor types. We can write the resulting system as three sets of equations (13)-(16). The first represents the derived demand conditions:

$$
q_{i}=\Sigma_{j} \theta_{j} \sigma_{i j} p_{j}+q \text { (derived demand) }
$$

where $i$ and $j$ are inputs, and $\sigma_{i j}$ is elasticity of substitution between inputs $i$ and $j$.

The second set of equations refer to the input supplies for the fixed factor, $L$ (unskilled labor in our case), and the perfectly mobile inputs whose supply are assumed to be perfectly elastic, hence prices are fixed:

$q_{L}=0$ and (factor supply condition for fixed input L: no quantity change)

$p_{j}=0$ (factor supply conditions, for input $j$ other than L: no price change)

Lastly, recall the zero profit condition (equation 12) derived above: $p=\Sigma_{j} \theta_{j} p_{j}$. Substituting (14) and (15) into (13) for $i=L$, we have:

$$
q_{L}=\theta_{L} \sigma_{L L} p_{L}+q=0 \quad \text { (equilibrium in the immobile factor market) }
$$

Equation (16) implies that the only way to expand output, $q$, while remaining in factor market equilibrium, is to save on the scarce factor, $L$. This is induced by a rise in factor price (wage rate), $p_{L}$, which in turn causes firms to substitute other inputs for $L$, according to the available technology determined by the elasticity of substitution.

From (12) and (15) we have:

$$
\left.p=\theta_{L} p_{L} \text { or } p_{L}=\theta_{L}^{-1} p \quad \text { (magnification effect }\right)
$$

Since all other input prices are fixed, in partial equilibrium, the only adjustment that can occur on the cost side is in the wage rate, $p_{L}$. The magnitude of this 
adjustment will be greater, the smaller the share of $L$ in total costs.

Substituting (17) into (16) and rearranging gives the supply response in terms of output price ${ }^{6}$ :

$$
q=-\sigma_{L L} p \quad \text { (supply response) }
$$

Therefore, the partial equilibrium supply elasticity (\% change in quantity divided by $\%$ change in prices) in this case is given by:

$$
\eta_{s}=q / p=-\sigma_{L L} \quad \text { (supply elasticity) }
$$

where $\sigma_{L L}$ is the own elasticity of substitution for input $L$. In other words, the sectoral supply response is simply determined by the industry's ability to substitute away from the fixed factor. If $\sigma_{L L}=0$, then price changes will not be able to induce any supply response. Furthermore, when output prices rise all the benefit will be transmitted to the return to sector-specific factor ${ }^{7}$. If the share of this factor in total costs is small, then the magnification effect can be substantial ${ }^{8}$.

The case of less-than perfect factor mobility is modeled in the standard GTAP model by introducing "sluggish endowment commodities" (Hertel 1997). These factors are distributed across uses according to a Constant Elasticity of Transformation (CET) function. Of particular interest here is the conditional own-price elasticity of supply, which is given by (Hertel 2000):

$$
v_{L L}^{j}=\Omega^{j}{ }_{L}\left(1-\Omega^{j-1}\right) \sigma_{E}=\left(\Omega^{j}{ }-1\right) \sigma_{E}
$$

where $\sigma_{E}<0$ is the elasticity of transformation of, say, labor endowments across uses in the $C E T$ function, and $\Omega^{j}{ }_{L}$ is the revenue share of the total labor endowment employed in sector $j .{ }^{9}$ The parameter $v^{j}{ }_{L L}$ describes the sensitivity of labor supply to sector $j$ in response to a change in the wage rate in sector $j$, i.e. $p_{L}^{j}$. To get this in terms of the change in output price, we use equation (17), which links percentage change in output price with the price of labor input. This labor supply equation replaces (14) in

\footnotetext{
${ }^{6}$ From (16) and (17), $q_{L}=\theta_{L} \sigma_{L L} p_{L}+q=0=>q=-\theta_{L} \sigma_{L L}\left(\theta_{L}^{-1} p\right)=>q=-\sigma_{L L} p$

${ }^{7} \mathrm{By}$ the formula linking input price with the output price $p: p_{L}=\theta_{L}^{-1 *} p$, where $\theta$ is the cost share of input L. In the case of single input $\theta_{L}=1$, hence $p_{L}=p$, which means percentage change in output price will be equal to percentage change in input price.

${ }^{8}$ For example if the cost share is $33 \%$, the increase in input return will be three times the increase in commodity price. i.e. $p_{L}=(1 / .33) p=3.03 p$

${ }^{9}$ Note from the above equation that if sector $j$ uses all the labor available in the economy, then $v_{l l}^{j}=0$ and we are effectively back in the previous case.
} 
the previous case, which yields the following partial equilibrium supply elasticity for sector $j$ :

$$
\bar{\eta}_{s}^{j}=-\sigma_{L L}^{j}+\left[\left(\Omega_{L}^{j}-1\right) / \theta_{L}^{j}\right] \sigma_{E}
$$

The above equation decomposes the partial equilibrium commodity supply response of sector $j\left(\eta_{s}^{j}\right)$ into two components: technology $\left(-\sigma_{L L}^{j}\right)$ and the remain$\left.\operatorname{der}\left[\left(\Omega_{L}^{j}-1\right) / \theta_{L}\right)\right] \sigma_{E}$, which is attributable to factor mobility.

Having overviewed the issue of factor mobility in general, we can now turn to treatment of agricultural unskilled labor mobility. The standard GTAP model has been modified in the following way to address the issue of agricultural unskilled labor mobility. The key point here is that unskilled labor is assumed to be perfectly mobile within agriculture (and non-agriculture), but imperfectly mobile between these two sectors ${ }^{10}$. According to this specification there are effectively two sectors for unskilled labor as depicted by Figure 1 below: agriculture being comprised of all primary agricultural sectors, and non-agriculture including all sectors other than agriculture i.e. processed food, industrial, and services sectors. The distribution of unskilled labor between agricultural and non-agricultural sectors is determined by the wage differential between the two sectors and elasticity of transformation (ETUSKL). In particular, ETUSKL is the analytical instrument to represent the imperfect character of unskilled labor mobility between farm and non-farm sectors pointed out by the empirical studies mentioned in the introduction.

Figure 1. Unskilled Labor Mobility between Agriculture and Non-agriculture

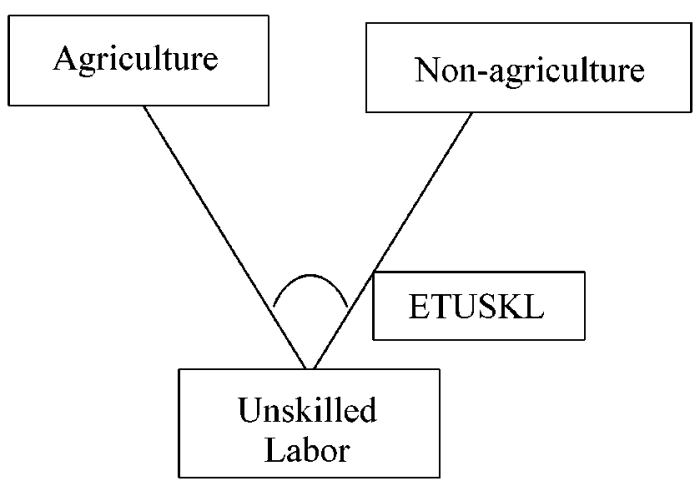

\footnotetext{
${ }^{10}$ For sluggish factors (i.e. land and natural resources) there is no distinction between agriculture and nonagriculture for they are assumed to be imperfectly mobile between all sectors.
} 
In order to handle this task in the model, first price and quantity variables for agricultural and non-agricultural unskilled labor are defined.

qousklagr $(r)=$ supply of unskilled labor to agricultural sectors, in region $r$, qousklnagr $(r)$

$=$ supply of unskilled labor to non-agricultural sectors, in $r$,

$\operatorname{pmuskl}(r) \quad=$ composite price of unskilled labor, in $r$, pmusklagr $(r)$

$=$ market price of unskilled labor used by agricultural sectors, in $r$, pmusklnagr $(r)$

$=$ market price of unskilled labor used by non-agricultural sectors, in $r$.

Second, elasticity of transformation parameter, ETUSKL, is introduced.

$\operatorname{ETUSKL}(r) \quad=$ elasticity of transformation for unskilled labor. i.e. how easy (or hard) it is to transform agricultural unskilled labor into non-agricultural unskilled labor. It is, by definition, non-positive. In other words, we expect a decline in agricultural unskilled labor supply when there is an increase in the price of unskilled labor in non-agriculture.

Third, all sectors are merged into two broad sectors (agriculture and nonagriculture) in terms of unskilled labor usage.

$\operatorname{VOMAGUL}(i, r)=$ value of $i$ (agricultural unskilled labor) in region $r$, which, in GTAP notation, turns into:

$$
=\operatorname{sum}\left(j, A G R \_C O M M, \operatorname{VFM}(i, j, r)\right) \text { and }
$$

$\operatorname{VOMNAGUL}(i, r)=$ value of $i$ (non-agricultural unskilled labor) in region $r$ $=\operatorname{sum}\left(j, N A G R \_C O M M, \operatorname{VFM}(i, j, r)\right)$

where

$A G R \_C O M M=\{$ primary agricultural sectors $\}$,

NAGR_COMM = non-agricultural sectors $\}$,

$\operatorname{VFM}(i, j, r) \quad=$ value of firms purchases of factor $i$ in sector $j$ in region $r$.

Fourth, shares of agricultural and non-agricultural unskilled labor in total payments to unskilled labor by firms (i.e. revenue shares of unskilled labor in farm and non-farm sectors, respectively) is computed by dividing the value of agricultural and non-agricultural unskilled labor by aggregate payments to unskilled labor 
in the economy.

$$
\begin{aligned}
\operatorname{REVSHRAGR}(i, r)= & \operatorname{sum}\left(j, A G R \_C O M M, \operatorname{VFM}(i, j, r)\right) / \\
& \operatorname{sum}\left(k, P R O D_{-} C O M M, \operatorname{VFM}(i, k, r)\right) \text { for agriculture, and } \\
\operatorname{REVSHRNAGR}(i, r)= & \operatorname{sum}\left(j, \operatorname{NAGR\_ COMM}, \operatorname{VFM}(i, j, r)\right) / \\
& \operatorname{sum}\left(k, P R O D_{-} C O M M, \operatorname{VFM}(i, k, r)\right) \text { for non-agriculture. }
\end{aligned}
$$

Market clearing conditions follow, which require equality of Supply and Demand for unskilled labor in each market. Starting from the level equations, supply of agricultural unskilled labor equals sum of demand for unskilled labor in individual agricultural sectors:

$$
L_{A}=\Sigma_{j} L_{A}^{j} \quad \text { (equilibrium condition in levels form) }
$$

Differentiating (22) gives

$$
d L_{A}=\Sigma_{j} d L_{j A}
$$

Dividing through by $L_{A}$ yields

$$
d L_{A} / L_{A}=\Sigma_{j}\left(d L_{A}^{j} / L_{A}\right)
$$

Multiplying right hand side by $\left(L_{A}^{j} / L_{A}^{j}\right)$, using the definition of cost share, and rearranging gives

$$
l_{A}=\Sigma_{j} \theta^{j} l_{A}^{j} \text { equilibrium condition in percentage form) }
$$

where lower case $l$ means percentage change. Same procedure applies to nonagricultural unskilled labor, which yields $l_{N A}=\Sigma_{j} \theta^{j} l^{j}{ }_{N A}$. In GTAP notation this can be expressed as:

$\operatorname{VOMAGUL}(i, r)^{*}$ qousklagr $(r)=\operatorname{sum}\left(j, A G R \_C O M M, \operatorname{VFM}(i, j, r)^{*} q f e(i, j, r)\right)$, $\operatorname{VOMNAGUL}(i, r)^{*} q$ ousklnagr $(r)=\operatorname{sum}\left(j, N A G R \_C O M M, \operatorname{VFM}(i, j, r) * q f e(i, j, r)\right)$.

Domestic and firm demand prices are linked in the following equations through taxes on unskilled labor input $i$ employed in sector $j$ in region $r$, which capture the 
effect of taxation of firms' usage of unskilled labor. In level form, tax on input $i$ in sector $j$ in region $r$ is given by value of firms' purchases at agents prices (VFA) over market prices $(V F M)$ :

$$
\begin{aligned}
T F(i, j, r) & =\operatorname{VFA}(i, j, r) / \operatorname{VFM}(i, j, r)=\operatorname{PFE}(i, j, r) Q F E(i, j, r) / P M(i, j, r) \operatorname{QFE}(i, j, r) \\
& =\operatorname{PFE}(i, j, r) / \operatorname{PM}(i, j, r)
\end{aligned}
$$

where $\operatorname{PFE}(i, j, r)$ and $\operatorname{QFE}(i, j, r)$ represent price paid and quantity demanded by firms' for endowment commodity $i$ in sector $j$ in region $r$, respectively. $P M$ denotes market price.

Given the fact that there is a single price for unskilled labor across agricultural sectors, in differential form equation (26) converts to

$$
t f(i, j, r)=p f e(i, j, r)-p m(r), \text { or } p f e(i, j, r)=t f(i, j, r)+p m(r)
$$

Replacing $i$ with $L$ in the above equation says that percent change in unskilled labor wages in sector $j$, say agriculture, will be percent change in market price of agricultural unskilled labor plus input taxes. Same thing applies to non-agriculture, too. Hence price paid by firms for agricultural and non-agricultural unskilled labor are given by:

$$
\begin{aligned}
& p f e(i, j, r)=t f(i, j, r)+\text { pmusklagr }(r) \\
& p f e(i, j, r)=t f(i, j, r)+\text { pmusklnagr }(r)
\end{aligned}
$$

Price of composite unskilled labor is calculated as the revenue share-weighted average of agricultural and non-agricultural unskilled labors.

$$
\begin{aligned}
& \operatorname{pmuskl}(\mathrm{r})=\operatorname{REVSHRAGR}(i, r) * \operatorname{pmusklagr}(\mathrm{r})+\operatorname{REVSHRNAGR}(i, r) \\
& \text { *pmusklnagr }(r)
\end{aligned}
$$

The distribution of unskilled labor between agricultural and non-agricultural sectors are determined by elasticity of transformation of agricultural unskilled labor (ETUSKL) multiplied by the wage differential. Starting from the definition of elasticity of substitution ( $L=$ Unskilled Labor, $a=$ agriculture $):{ }^{11}$

$$
\sigma_{\text {ETUSKL }}=\frac{\left(Q_{L}^{a} / Q_{L}\right)}{\left(P_{L}^{a} / P_{L}\right)}<0 \Rightarrow\left(Q_{L}^{a} / Q_{L}\right)=\sigma_{E T U S K L}\left(P_{L}^{a} / P_{L}\right)
$$

${ }^{11}$ Same procedure applies to nonagriculture. 
In percent change form this converts to

$$
q_{L}^{a}-q_{L}=\sigma_{\text {ETUSKL }}\left(p_{L}^{a}-p_{L}\right) \text { or, } q_{L}^{a}=q_{L}+\sigma_{\text {ETUSKL }}\left(p_{L}^{a}-p_{L}\right)
$$

Equation (32) tells us that if percent change in unskilled agricultural labor exceeds percent change in composite unskilled labor, we expect an increase in unskilled agricultural labor supply relative to total labor supply, and vice versa. The magnitude of relative change will be determined by relative wage differential and the size of the elasticity parameter.

\section{Data, Calibration and Experimental Design}

\section{A. Data}

Before going into experimental design and the simulations, a few words on the data are in order. The GTAP 4 data base is utilized for the empirical investigation part of this paper. The data base contains detailed bilateral trade, transport, and protection data characterizing economic linkages between regions, and individual country input-output tables accounting for inter-sectoral linkages within each region. The database is built on a complete set of economic accounts for each of the 45 regional economies. Some of these regions are individual countries, whereas some others include a group of countries. The data are based on the year 1995 and incorporate an exhaustive description of inter-industry linkages among 50 sectors within each region. Both intermediate input and import compositions are

Table 1. Commodity Aggregation

\begin{tabular}{rcc}
\hline$\#$ & Code & Sector \\
\hline 1 & gos & Grains and oilseeds \\
2 & $l v s$ & Livestock \\
3 & VaF & Vegetables and fruits \\
4 & ocr & Other crops \\
5 & $f a f$ & Forestry and fishing \\
6 & $m t p$ & Meat products \\
7 & dap & Dairy products \\
8 & $b t p$ & Beverages and tobacco products \\
9 & $o f p$ & Other food products \\
10 & $t e x$ & Textiles \\
11 & WAP & Wearing apparels \\
12 & OIS & Other Industrial Sectors \\
\hline
\end{tabular}


Table 1. Cost shares of primary factors in agricultural sectors, Turkey

\begin{tabular}{c|cccl}
\hline & GOS & LVS & VAF & OCR \\
\hline Land & 0.22 & 0.13 & 0.25 & 0.27 \\
Unskilled Labor & 0.35 & 0.20 & 0.40 & 0.42 \\
Skilled Labor & 0.02 & 0.01 & 0.02 & 0.02 \\
Capital & 0.07 & 0.04 & 0.07 & 0.08 \\
\hline
\end{tabular}

Source: The GTAP 4 data base, Yeldan and Köse (1996).

allowed to change across different uses. ${ }^{12}$

The original $I O$ data for Turkey is taken from The Input-Output Structure of the Turkish Economy 1990 published by State Institute of Statistics of Turkey (1994). It is modified in accordance with the additional data provided by Yeldan and Köse (1996). This $I O$ table is incorporated into the GTAP 4 data base in order to separate out Turkey for quantitative analysis. ${ }^{13}$ Agricultural sectors and labor categories are disaggregated by following a series of procedures explained in detail in Peterson (1998), Liu and McDougall (1998), and Liu et al. (1998). The following table shows the sectoral aggregation, which includes 12 sectors: 5 primary agricultural, 4 processed food, and 3 industrial sectors.

The issue of imperfect agricultural unskilled labor mobility is quite relevant in the case of Turkey-EU customs union due to its possible implications on output changes and sectoral reallocations given the relatively high share of agriculture in the Turkish economy and unskilled labor-intensive character of agriculture. As depicted by Table 1 below, cost shares of unskilled and skilled labor are 35\% and $2 \%$ in grains and oilseeds, $20 \%$ and $1 \%$ in livestock, $40 \%$ and $2 \%$ in vegetables and fruits, $42 \%$ and $2 \%$ in other crops and forestry-fishing sectors, respectively.

Implications of unskilled labor mobility are investigated in this section by applying the model developed above to agricultural integration between Turkey and the $E U$. Data calibration, experimental design and the results follow.

\section{B. Calibration for ETUSKL}

The calibration of ETUSKL is an empirical question, which involves revenue shares and estimations of own price elasticity of unskilled labor supply. This can be done by using the link between own price elasticity of unskilled labor supply

\footnotetext{
${ }^{12}$ The sectoral and regional aggregation of the data base can be found in McDougall et al. (1998). Simulations had to rely on an older version of data base (GTAP 4) due to unavailability of a more recent Turkish $I O$ table.

${ }^{13}$ Incorporation of Turkish data into GTAP 4 data base, concordance and reconciliation procedure is explained in detail in Acar (1998).
} 
Table 2. ETUSKL and Unskilled Labor Supply Elasticities

\begin{tabular}{c|ccccc}
\hline & $\begin{array}{c}\text { Agricultural } \\
\text { USKL }\end{array}$ & Total USKL & Revenue share & $\begin{array}{c}\text { Implied } \\
\text { USKL } \\
\text { supply elasticity }\end{array}$ & ETUSKL \\
\hline TUR & 13265 & 57979 & 0.229 & 2.638 & -3.421 \\
$E U$ & 129330 & 3145092 & 0.041 & 3.280 & -3.421 \\
$R O W$ & 413825 & 6127334 & 0.068 & 3.190 & -3.421 \\
$U S A^{*}$ & 37520 & 2514868 & 0.015 & 3.370 & -3.421 \\
\hline
\end{tabular}

*USA is put for reference purposes. Source: The GTAP 4 data base and own calculations.

and elasticity of transformation parameter. Recall that the conditional own-price elasticity of supply for input $L$ is given by equation (20), replacing $\sigma_{E}$ with $\sigma_{E T U S K L}$ :

$$
v_{L L}^{j}=\Omega^{j}{ }_{L}\left(1-\Omega^{j-1}{ }_{L}\right) \sigma_{\text {ETUSKL }}=\left(\Omega^{j}{ }_{L}-1\right) \sigma_{\text {ETUSKL }}
$$

where $\sigma_{\text {ETUSKL }}<0$ is the elasticity of transformation of unskilled labor across uses in the $C E T$ function, and $\Omega^{j}{ }_{L}$ is the revenue share of the unskilled labor employed in sector $j$ (i.e. share of unskilled labor employed in primary agricultural sectors with respect to total payments to unskilled labor). The parameter $v^{j}{ }_{L L}$ describes the sensitivity of labor supply to sector $j$ in response to a change in the labor wage rate in sector $j$. Note from the above equation that if sector $j$ uses all the unskilled labor available in the economy, then $v_{L L}^{j}=0$, which implies perfectly immobile labor supply.

There are two possibilities to calibrate elasticity of transformation parameter, ETUSKL. Either we can calibrate it with the help of revenue shares from individual regions' $I O$ flow data. This approach implies fixed labor supply elasticities $\left(v_{L L}^{j}\right)$ across regions. Alternatively, we can calibrate ETUSKL for a given labor supply elasticity for a sample region, hold it fixed across regions and let the implied unskilled labor supply elasticities vary. The second approach, which is preferred in this study, seems more plausible since it allows labor supply elasticity to vary across regions. It seems more reasonable to assume that labor supply elasticity is not the same for different regions given the considerable differences in factor intensities, degree of market segmentation and the development of economic infrastructure among various regions.

With regard to the value of labor supply elasticity, the ideal case would be to get estimations of agricultural unskilled labor supply elasticity for each individual region, which is not readily available for most regions. In the absence of local estimation for individual regions, then, we looked for an estimation based on relatively more reliable data. A recent estimation of agricultural unskilled labor 
supply elasticity is provided by Perloff (1991) for the US economy.

Perloff (1991) discussed the impact of wage differentials on choosing to work in agriculture. Based on a model of industry choice and wage determination, and using 1988 US data, he estimates that the response of average agricultural unskilled labor to a $1 \%$ increase in the relative wage in agriculture is $3.37 \%$. In another study Rosenbloom (1991) discussed the occupational differences in labor market integration for the US in the 1890s and estimated unskilled labor supply elasticity as 2.23 . Even though the latter estimation is related to labor supply elasticity between urban jobs rather than between agriculture and non-agriculture, nevertheless it gives an idea about the range in which labor supply elasticity can fluctuate.

The revenue share of agricultural unskilled labor is calculated for each region from the GTAP 4 data base and the implied ETUSKL value for the US is calculated using the above link between labor supply elasticity and the revenue shares. Holding it fixed, the implied labor supply elasticities are also calculated in Table 2 , which reports payments to agricultural unskilled labor, revenue shares and the implied supply elasticities for all regions.

\section{Experimental Design}

The 1995 Customs Union agreement between Turkey and the $E U$ has been effective since 1996 and it was projected to be completed by 2001. The agreement excluded agricultural sectors, but kept the door open for future agricultural integration (Article 22, Customs Union With EU, 1995). One of the possibilities before the Turkish Government, which is in need of deciding the future of agricultural policies, therefore, is to evaluate the possible costs and benefits of integrating Turkey's agriculture with that of the EU. Acar (2000) investigates the implications of agricultural integration in many respects, i.e. welfare, sectoral reallocations, factor markets, cost on the $E U$ budget, revenue replacement, etc. The experiment designed for the simulations below draws partly on this study.

The experiment designed to explore the empirical implications of agricultural unskilled labor mobility is called AGIA_01 (Agricultural Integration After 2001). It is a projection for the future and looks into the implications of agricultural integration after the year 2001 once the industrial integration is completed. For this purpose, essentially all trade barriers between Turkey and the $E U$ are removed, i.e. import tariffs and export subsidies are eliminated, and Turkey adapts the common external tariffs of the $E U$ against other regions. 
Table 3. Impact of unskilled labor mobility on output response, Turkey, AGIA_O1

\begin{tabular}{|lrc|}
\hline & Perfect mobility & Imperfect mobility \\
\hline GOS & 5.8 & 4.3 \\
VAF & 4.9 & 2.4 \\
OCR & 2.9 & 2.0 \\
$F A F$ & 10.2 & 6.7 \\
MTP & -4.0 & -2.1 \\
$D A P$ & 29.4 & 11.5 \\
BTP & 3.6 & 3.3 \\
$O F P$ & -1.8 & -0.5 \\
TEX & -7.8 & 4.7 \\
WAP & 59.4 & 13.6 \\
OIS & 172.0 & 88.5 \\
\hline
\end{tabular}

Source: simulation results

The experiment applies the policy shocks in two stages. In the first stage harmonization is applied only to industrial sectors as proposed by the $1995 C U$ agreement. In the second stage agricultural sectors are integrated by removing the trade distortions and extending the common agricultural tariffs to include primary agricultural sectors. Output subsidies are also harmonized with the $E U$. What is important for the focus of this study is to see if different mobility assumptions would make a visible difference in terms of output response and reallocation of resources.

\section{Empirical Implications: Simulation Results}

The relevance of the imperfect mobility of unskilled labor between sectors has been emphasized previously. When factors are assumed to be infinitely elastic, i.e. perfectly mobile between alternative uses, then supply response would be higher compared to imperfect factor mobility case. In this section the extend to which the results are affected by different treatments of labor with regard to intersectoral mobility is going to be highlighted. First, an example is chosen to highlight the impact on sectoral output response when unskilled labor is treated imperfectly mobile between sectors. Table 3 gives the output response in E1 under perfect and imperfect factor mobility assumptions.

The first column gives the output response when unskilled labor is treated imperfectly mobile between all sectors, agriculture and non-agriculture alike. The second column does the same thing for perfectly mobile unskilled labor. As 
Table 4. ETUSKL and Corresponding Labor Supply Elasticities

\begin{tabular}{|c|c|c|c|c|}
\hline & & $\begin{array}{c}\text { ETUSKL } \\
=0.0\end{array}$ & $\begin{array}{c}\text { ETUSKL } \\
=-2.030\end{array}$ & $\begin{array}{c}\text { ETUSKL } \\
=-3.045\end{array}$ \\
\hline $\begin{array}{c}\text { Revenue } \\
\text { share of } \\
\text { USKL }\end{array}$ & $\begin{array}{c}\text { Unskilled } \\
\text { Labor supply elasticity }\end{array}$ & $\begin{array}{c}\text { Unskilled } \\
\text { Labor supply elasticity }\end{array}$ & $\begin{array}{c}\text { Unskilled } \\
\text { Labor supply elasticity }\end{array}$ \\
\hline$T U R$ & 0.229 & 0.0 & 1.56 & 2.35 \\
\hline$E U$ & 0.041 & 0.0 & 1.94 & 2.92 \\
\hline$R O W$ & 0.068 & 0.0 & 1.89 & 2.84 \\
\hline$U S A$ & 0.015 & 0.0 & 2.0 & 3.0 \\
\hline
\end{tabular}

Source: The GTAP 4 data base and own calculations

indicated by figures in Table 3, when factors are freely mobile across all sectors, supply response is remarkably higher in most sectors relative to imperfect mobility case. This is more visible especially in meat products (MTP), textiles (TEX), and wearing apparels $(W A P)$, which are relatively more heavily protected sectors. For instance, estimated output growth in WAP in the case of perfect factor mobility is $168 \%$ as opposed to $87 \%$ in the imperfect mobility case, 81 percent points higher in the former case. Similarly, MTP expands by $27.3 \%$ in perfect mobility case compared to $12.4 \%$ of imperfect mobility case.

Economically these results are hardly surprising: when trade distortions are removed, foreign demand as well as domestic demand will respond positively to increasing export prices and falling input costs via reduced import prices. Derived demand for factors will go up in expanding sectors. If factors are freely mobile between sectors, it will be easier to pull additional factors from other sectors. The easier to get these additional factors, the higher would be the supply response. Percentage increases are more visible in MTP, TEX, and WAP sectors because protection is heavier in these sectors, and the last two sectors have a considerable share in Turkey's foreign trade with the EU.

The above results indicate that it matters whether you to treat unskilled labor perfectly or imperfectly mobile between all sectors. What about treating unskilled labor imperfectly mobile between two broader categories, farm and non-farm sectors? In this context, let's go one step further and look at the response of output under different assumptions of unskilled labor mobility between agriculture and non-agriculture.

Recall that ETUSKL and unskilled labor supply elasticity are linked through the revenue share of unskilled labor in a given economy (equation 20). The following table shows different values of elasticity of transformation of unskilled labor and 
the corresponding unskilled labor supply elasticities.

Notice that when elasticity of transformation is assumed to be zero, the implied unskilled labor supply elasticity will also be zero, i.e. there is no way of using agricultural unskilled labor as non-agricultural unskilled labor. This means unskilled labor is perfectly immobile between farm and non-farm sectors. The second and third columns correspond to implied labor supply elasticities for Turkey, $E U$ and Rest of the World when labor supply elasticity of the $U S$ is assumed to be 2.0 and 3.0 respectively.

In light of the above, Figure 2 below shows the output response in primary agricultural sectorsgrains and oil seeds, livestock, vegetables and fruits, other crops, and forestry and fishingof Turkey under different mobility assumptions mentioned above. The first, second and third columns in Figure 2 represent output

Figure 2. Output response under different mobility assumptions, \%, Turkey, AGIA_01

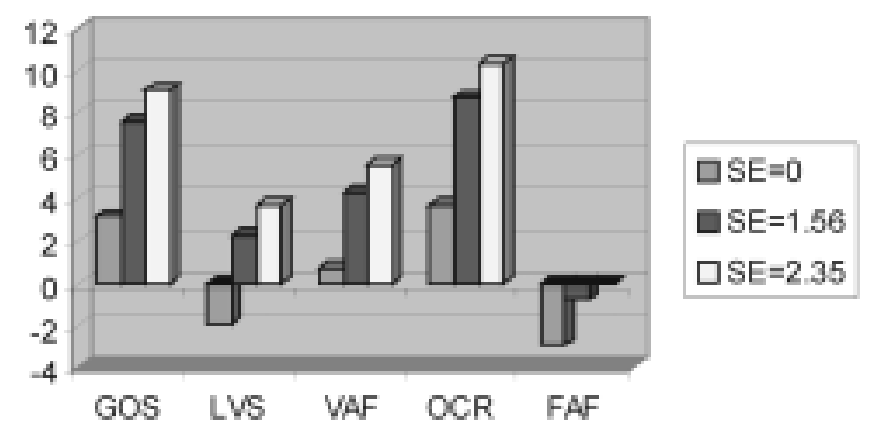

Figure 3. Real Factor Returns, \% change, Turkey, AGIA_01

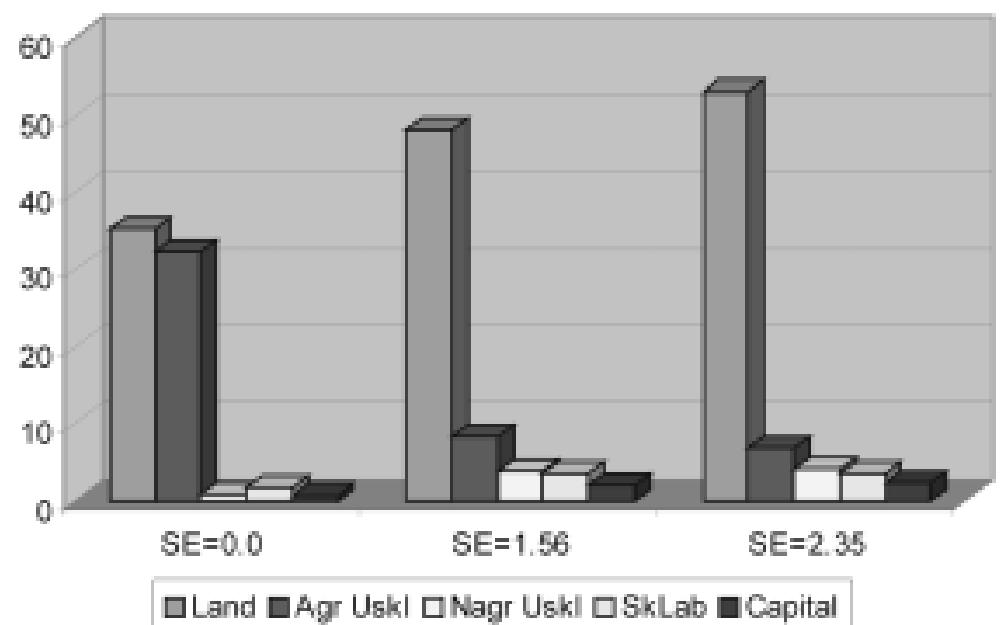

Source: Simulation results 
response for each sector when unskilled labor supply elasticity is assumed to be zero (perfectly immobile), 1.56 and 2.35, which correspond to elasticity of transformation of unskilled labor $(E T U S K L)=0.0,-2.03$ and -3.05 respectively.

As the figure shows, output response is minimum when labor supply elasticity is zero, i.e. unskilled labor is fixed. Output response gets higher as we relax this assumption and allow unskilled labor mobility between agriculture and nonagriculture. For example, GOS sector expands only by about $3 \%$ when unskilled labor is not mobile, while it expands more than $7 \%$ and about $9 \%$ when labor supply elasticity is assumed to be 1.56 and 2.35 , respectively. The rate of expansion jumps up when we switch from perfect immobility to a moderate level of mobility. Same trend applies more or less to other primary agricultural sectors as well. The implication of this finding on factor returns, however, is in the opposite direction, as revealed by Figure 3 below, which shows the impact of agricultural integration on real factor prices in Turkey under different mobility assumptions.

The role of agricultural unskilled labor mobility on real factor returns is clearly reflected in the above figure. Recall that in the scenario, agricultural sectors are included in the Customs Union after the industrial integration is completed. As a result of removing all trade barriers for agricultural sectors and harmonizing output subsidies with the $E U$, most of the agricultural sectors tend to expand as reflected by Figure 2. Accordingly we expect real factor returns to be positive and higher returns for those factors used intensively in agricultural sectors. This is confirmed by Figure 3. A closer look at the figure can tell more on the impact of unskilled labor mobility between farm and non-farm sectors.

As indicated by Figure 3, real returns on agricultural unskilled labor are the highest (32.3\%) when no intersectoral factor mobility is allowed, nearly as high as return on land $(35.2 \%)$, which is another sector-specific factor. As we allow unskilled labor mobility, that means we are moving away from sector-specific nature of unskilled labor. This results in loosening the strong link between factor

Table 5. Changes in price and quantity of Unskilled Labor, \%, AGIA_01

\begin{tabular}{c|ccc}
\hline & TURKEY & \multicolumn{1}{c}{$E U$} & ROW \\
\hline Agricultural unskilled labor supply & 7.39 & -0.36 & 0 \\
Non-agricultural unskilled labor supply & -2.13 & 0.02 & 0 \\
Price of agricultural unskilled labor & 10.59 & -0.52 & 0.07 \\
Price of non-agr. unskilled labor & 7.63 & -0.41 & 0.07 \\
Average price of unskilled labor & 8.31 & -0.42 & 0.07 \\
\hline
\end{tabular}

Source: Simulation results 
Table 6. Impact on export volume (Turkey to the $E U$, \$m, 1995 prices, AGIA_01)

\begin{tabular}{|c|r|r|r|}
\hline & $\mathrm{SE}=0.0$ & $\mathrm{SE}=1.56$ & $\mathrm{SE}=2.35$ \\
\hline GOS & 17.1 & 19.9 & 20.9 \\
\hline$L V S$ & 42.6 & 50.6 & 53.2 \\
\hline$V A F$ & 223.8 & 419.2 & 480.7 \\
\hline$O C R$ & 135.0 & 150.8 & 155.6 \\
\hline$F A F$ & -13.6 & -10.0 & -8.8 \\
\hline$M T P$ & 13.5 & 13.9 & 14.1 \\
\hline$D A P$ & 1.83 & 1.84 & 1.84 \\
\hline$B T P$ & 5.6 & 6.1 & 6.2 \\
\hline$O F P$ & 309.7 & 327.1 & 332.3 \\
\hline
\end{tabular}

Source: Simulation results

returns and output price, which dampens the real return on unskilled labor, hence reducing the gap between return on farm and non-farm unskilled labor. For instance, real earnings gap between agricultural and non-agricultural unskilled labor is quite high $(32.3-0.81=31.49 \%)$ when no factor mobility is allowed. It falls sharply to $4.54 \%(8.35-3.81)$ when labor supply elasticity is taken to be 1.56 . When even higher levels of factor mobility is introduced, agricultural unskilled labor loses its sector-specific nature almost completely; hence non-agricultural unskilled labor earns more than agricultural labor (4.76 vs. 0.81 respectively under labor supply elasticity of 2.35).

Real return on land is the highest relative to all other factors of production in all cases. This is because land is always used as a sector-specific factor employed only in the primary agricultural sectors. As labor supply elasticity goes up from zero, while farm unskilled labor earnings get reduced, return on land increases even further. This, once again, follows from the strong relationship between the price of sector-specific factor and the price of output in that sector and the level of support. As unskilled labor mobility is allowed, land becomes the only sectorspecific factor, and hence getting the highest return as agricultural sectors expand. The following table highlights further what happens to prices and quantities of unskilled labor in the case of agricultural integration.

When agriculture is included in the integration, most agricultural sectors expand as mentioned earlier, which calls for more primary factor usage to accommodate increased demand. Since primary agricultural sectors are unskilled labor intensive, agricultural unskilled labor supply goes up by $7.39 \%$ while non-agricultural unskilled labor supply goes down by $2.13 \%$ in Turkey. Accordingly, prices of agricultural unskilled labor increases faster (10.59\%) than that of skilled labor (7.63\%). 
The second column indicates that agricultural integration with Turkey will negatively effect unskilled agricultural labor supply and wages in the $E U$ though the magnitude is not high.

Finally we will take a look at the impact of labor mobility on exports of Turkey to the $E U$ in the case of agricultural integration. Table 6 shows estimated changes in export volume in million dollar terms under three different unskilled labor supply elasticity $(S E)$ assumptions in primary agricultural and food processing sectors.

As far as the impact of unskilled labor mobility on exports is concerned, one can observe a similar trend with that of output and factor returns. That is, as we allow higher degrees of mobility, response of exports also gets higher. For example $\$ 223$ million worth of export volume change in vegetables and fruits $(V A F)$ sector in 1995 prices $^{14}$ in the case of perfect immobility goes up to $\$ 419.2$ million and $\$ 480.7$ million, respectively, when unskilled labor elasticity is assumed to be 1.56 and 2.35 respectively. Similarly, other crops (OCR) sector starts with an export volume change of $\$ 135$ million in strict immobility and climbs to $\$ 150.8$ and $\$ 155.6$ million as unskilled labor is allowed to move between farm and non-farm at various degrees. This trend applies to all primary agricultural and food processing sectors, except for forestry and fishing $(F A F)$ sector, which seems to have no chance for increasing exports.

\section{Summary and Conclusions}

Labor mobility is an important issue in quantitative economic analyses due to its possible implications for the sectoral reallocation of factors of production, output response, prices, and wages. This paper investigates the issue of agricultural unskilled labor mobility from both modeling and empirical perspectives. There is a fair amount of evidence in the literature that there is a certain degree of market segmentation between agriculture and non-agriculture, which implies that the labor force cannot freely and perfectly move from farm and non-farm sectors. In this study this imperfect mobility is modeled by linking labor supply with the wage differential through an elasticity of transformation parameter. After discussing the issue from a theoretical perspective, I look into the empirical implications of treating agricultural unskilled labor less than perfectly mobile in the context of

\footnotetext{
${ }^{14}$ Dollar value of quantity changes at initial (1995) prices.
} 
Turkey-EU agricultural integration.

The results indicate that degree of mobility of the agricultural unskilled labor matters: it has certain implications on sectoral output, reallocation of resources, and accordingly factor returns. I found that the higher the degree of unskilled labor mobility between farm and non-farm sectors, the higher the output response, and the lower the real earnings of unskilled labor in agriculture, and vice versa. Export volumes also go up faster as unskilled labor is allowed to move between farm and non-farm sectors.

In the context of a possible Turkey-EU agricultural integration in the post-2001 era, the findings indicate that output response is minimum when labor supply elasticity is set to zero, i.e. unskilled labor supply is fixed within farm and non-farm sectors. It gets higher as we allow unskilled labor mobility. The rate of expansion in farm sectors doubles when labor supply elasticity changes from zero to 1.56. Upward trend in output and export volumes is quite visible in all primary agricultural sectors and textiles and wearing apparels. The impact of this result on factor returns, however, is negative. Real return on unskilled labor gets lower, the higher the mobility. As labor becomes non-sector specific, real returns fall.

Naturally, these findings have important policy implications for a country like Turkey where agriculture accounts for about $14 \%$ of GDP, agricultural products constitute $10 \%$ of total exports and finally, more than $40 \%$ of civilian labor force is employed in farm sectors. Turkey is a transition economy moving from agricultural to industrial society, from a heavily protected to an open, free market economy. Integration with the $E U$ is an integral part of this transition process. Although steadily declining, agriculture still constitutes a considerably larger portion of $G D P$ and civilian employment relative to $E U$ members and other industrial nations. In this framework, it is crucial for the policy makers to take the implications of the degree of labor mobility into account when deciding the future agricultural policies. Higher unskilled labor mobility means higher migration from rural to urban, from farm to non-farm jobs in case of agricultural contraction. The movement will be to the other direction in case of agricultural expansion. Achieving a competitive industrial economy calls for a smaller farm sector, but this requires other supplementary policies to expand the capacity of urban centers to create more jobs.

In light of the above discussion, an important area for further research comes out. Given the finding that different levels of labor supply elasticity, hence varying degrees of labor mobility lead to considerably different results as far as the impact 
of a regional economic integration project on sectoral reallocations, factor earnings and export volumes are concerned, it would be a critical area to look into the magnitude of unskilled labor supply elasticity for a particular region in question. More refined estimation of labor supply elasticity would generate more plausible results for quantitative economic analyses.

\section{Acknowledgement}

I am grateful to Professor Tom Hertel for his valuable help in modeling agricultural unskilled labor mobility, and I would like to thank one anonymous referee for his/her useful comments and suggestions. All remaining errors are mine.

Received September 2001, Accepted January 2002

\section{References}

Acar, M. and R. McDougall (1998), "Agricultural Protection: non-OECD Countries," Chapter 13.3 in McDougall R.A., A. Elbehri, T.P. Truong, eds., Global Trade, Assistance and Protection: The GTAP 4 Data Base, Center For Global Trade Analysis, Purdue University.

Acar, M (1998), "Turkey," Chapter 14.12 in McDougall R.A., A. Elbehri, T.P. Truong, eds., Global Trade, Assistance and Protection: The GTAP 4 Data Base, Center For Global Trade Analysis, Purdue University.

Acar, M. (2000), "The Role of Agriculture in the Turkey-EU Customs Union: Implications of Extending the Customs Union, unpublished PhD Thesis, Purdue University, USA.

Alston, L.J. and T.J. Hatton (1991), "The Earnings Gap Between Agricultural and Manufacturing Laborers, 1925-1941," The Journal of Economic History 51 (March 1991): 83-99.

Barkley, A.P. (1990), "The Determinants of the Migration of Labor out of Agriculture in the United States, 1940-1985," American Journal of Agricultural Economics 72 (August 1990): 567-73.

Clark, C. (1957), The Conditions of Economic Progress. London: McMillan. $3^{\text {rd }}$ ed.

Customs Union With EU (1995), Intermedia, Istanbul.

Gehlhar, M. (1998), "Trade Data," Chapter 11 in McDougall R.A., A. Elbehri, T.P. Truong, eds., Global Trade, Assistance and Protection: The GTAP 4 Data Base, Center For Global Trade Analysis, Purdue University.

The GTAP 4 Data Base (1998), Center For Global Trade Analysis, Purdue University. 
Hatton, D.J., and J.G. Williamson (1991a), "Integrated and Segmented Labor Markets: Thinking in Two Sectors," Journal of Economic History 51(June 1991): 413-25.

Hatton, D.J., and J.G. Williamson (1991b), "Wage Gap Between Farm and City: Michigan in the 1890s," Explorations in Economic History 28(March 1991): 381-408.

Hertel, T.W. (1989), "Negotiating Reductions in Agricultural Support: Implications of Technology and Factor Mobility," American Journal of Agricultural Economics, 71(3), 559-573.

Hertel, T.W. (1997), eds., Global Trade Analysis: Modeling and Applications, New York: Cambridge University Press.

Hertel, T. W. (2000), Applied General Equilibrium Analysis, class notes, module 5, http:/ /www.agecon.purdue.edu/gtap/courses/gtapmodules.

Liu, J. and R. McDougall (1998), "Disaggregation of Input-Output Tables," Chapter 16 in McDougall R.A., A. Elbehri, T.P. Truong, eds., Global Trade, Assistance and Protection: The GTAP 4 Data Base, Center For Global Trade Analysis, Purdue University.

Liu, J., N. van Leeuwen, T.T. Vo, R. Tyers and T. Hertel (1998), "Disaggregating Labor Payments by Skill Level," Chapter 18 in McDougall R.A., A. Elbehri, T.P. Truong, eds., Global Trade, Assistance and Protection: The GTAP 4 Data Base, Center For Global Trade Analysis, Purdue University.

Patterson, P.M. (1998), "Hysteresis and the Shortage of Agricultural Labor," American Journal of Agricultural Economics 80(November 1998): 683-695.

Perloff, J.M. (1991), "The Impact of Wage Differentials on Choosing to Work in Agriculture," American Journal of Agricultural Economics 73(August 1991): 671-80.

Peterson, E. (1998) "Disaggregating Agricultural and Food Sectors," Chapter 15 in McDougall R.A., A. Elbehri, T.P. Truong, eds., Global Trade, Assistance and Protection: The GTAP 4 Data Base, Center For Global Trade Analysis, Purdue University.

Rosenbloom, J.L. (1991), "Occupational Differences in Labor Market Integration: The United States in 1890", The Journal of Economic History 51 (June 1991): 427-439.

Squire, L. (1981), Employment Policy in developing Countries, Oxford: Oxford Univ. Press.

The Input-Output Structure of the Turkish Economy 1990, State Institute of Statistics, Publication no. 1693, Ankara, 1994.

Williamson, J.G. (1987), "Did English Factor Markets Fail During the Industrial Revolution?" Oxford Economic Papers 39, 641-678.

Yeldan, E. and A. Kose (1996), "Türkiye Ekonomisinde Sektörel I ş gücü I stihdami ve Ücret Yap1s1 Üzerine Bir Deneme" (A Paper on the Sectoral Employment and Wage Structure in the Turkish Economy), I ktisat, İ şletme ve Finans, 11(118), 11-25. 